\title{
Australian tax strategy the hope for research boost
}

\section{Sydney}

PROPONENTS of Australia's innovative scheme to stimulate industrial research and development through massive tax concessions are enthusiastic about its performance. The latest estimates from the Department of Industry, Technology and Commerce (DITAC) suggest that total private enterprise research and development expenditure has risen by 43 per cent in real terms in the first year of the scheme's operation.

The tax concession, introduced in July 1985 , allows a company to deduct $\mathrm{A} \$ 1.50$ from its taxable income for every dollar spent on research or technical development. As the maximum rate of corporation tax is 49 per cent that means, for a company in profit, that for each dollar spent on research and development a company need spend only 26.5 cents. Research and development is generously defined and includes support activities, such as industrial design, operations research and software development.

Kevin Bryant, director of indicators and resource analysis within the Department of Science, claims the increase in research and development expenditure is indicative of revolutionary changes in attitude. Research and development expenditure actually began to rise before the tax scheme was in place, with a 19 per cent increase scored in 1984-85. But Bryant believes that many companies began to gear up to take advantage of the scheme as soon as it was announced in December 1984. And since then the pace has increased.

The tax concession has also changed corporate culture, according to John McKenna, director of research and development policy within DITAC, by presenting accountants with a strong reason to take note of research.

Problems do remain, however, and the scheme is still thought to be underexploited. Michael Johnson, a Sydneybased taxation consultant, estimates that there are 80,000 companies expected to be carrying out some research and development. But only 2,100 have registered their intention to take advantage of the scheme. One problem, Johnson says, is that the tax benefit is a corporate one and of no direct benefit to the research departments themselves.
Charles Morgan

\section{Japanese mill given credit for stealthy Soviet subs}

Washington and Tokyo

JAPAN's Prime Minister, Yasuhiro Nakasone, on an visit to Washington last week aimed at reducing Japanese-US trade friction, found that it is not just exports to the US that are worrying officials. At a National Press Club luncheon he was brought to task over exports to the Soviet Union of machinery that is helping Soviet submarines evade US coastal defences.

At issue is the export of four huge milling machines, and the computer program to control them, by Toshiba Machine Company. The machines can mill complex shapes in steel and it is claimed that the Soviets have used them to produce sophisticated submarine propellers that generate very little noise. From last year, US sonar systems began to detect Soviet submarines that were very much quieter than those found earlier, and extremely difficult to track.

Nakasone called the incident "very regrettable" and said that the police would investigate the matter as a criminal offence. Both the milling machine and its program are covered by COCOM regulations designed to prevent high-technology sales to Eastern bloc countries. Police in Tokyo have already searched the head offices of Toshiba Machine and the Ministry of International Trade and Industry claims that false information had been given by the company on export documents. But officials accompanying Nakasone say that key information for silencing Soviet submarines came not from Japan, but from a US spy ring.

Alun Anderson \& David Swinbanks

\section{Soviets out of ODP}

Washington

To the dismay of participants in the multinational Ocean Drilling Program (ODP) meeting in College Station, Texas, President Ronald Reagan has decided that the Soviet Union should not be invited to become a member of ODP. The Soviet Union had been asked to join two years ago, and a US delegation was poised to go to Moscow last February for a formal signing ceremony. But at the last moment, the Pentagon raised national security concerns because Soviet scientists would have access to sophisticated technology aboard the drilling ship. Officials at the National Science Foundation claimed there was no basis for such concerns, but were overruled by the president and his National Security Council. Joseph Palca

\section{Another try for research push}

\section{London}

A NOVEL centre to coordinate the commercial exploitation of current scientific research while encouraging new directions is in its final stages of planning. Its brief is to pick 'winners' for British industry. The institute, the brainchild of the Cabinet Office and the scientific advisors to the government's ACARD (the Advisory Council for Applied Research and Development), is expected to be housed at one of Britain's top science universities. Imperial College in London, Cranfield Institute of Technology in Bedfordshire, Warwick University in the Midlands and the London-based Technical Change Centre are among the front runners.

Sir Francis Tombs, chairman of Rolls Royce and ACARD, has managed to acquire much of the money needed to create the centre, a budget in the region of $£ 5$ million. The Tombs approach was highlighted in an ACARD report of last year which concluded that: "A process is needed to prioritize and guide a substantial proportion of that part of the national scientific resource be it Research Councils, Ministry of Defence or Department of Trade and Industry, and to stimulate its effective exploitation to the benefit of the United Kingdom".

Economic and management consultants Segal Quince Wicksteed, who have expertise in the commercialization of research, were appointed last year to steer ACARD, and the government, towards the creation of the centre. The consultancy has completed its study, from which an outline of the new centre has been derived.

In some respects the new centre will perform some of the tasks of the American Office of Technology Assessment which advises Congress but the British model will be independent from government. The Japanese MITI (Ministry of International Trade and Industry) which develops much of the successful policies behind Japan's industrial expansion has also inspired the British.

There have been several previous attempts to bring industry to the attention of university researchers and vice versa. The National Enterprise Board (NEB), which held substantial stakes in the British industries that needed investment, and the National Research Development Corporation (NRDC), which encouraged start-ups, were merged into the British Technology Group (BTG), supposedly to help exploit the scientific research effort. The current government has never disguised its dislike of the BTG and curbed its influence by encouraging academics to exploit their own research. Bill Johnstone 